ness of the institution, took upon themselves to forward to the Poor-law Commissioners the two notes of request of the medical officer, stating that they had ascertained he was in gaol, and declining to deal with his case. The result was a letter from the Commissioners calling on this officer to " resign," and that within a few days of his second application to the committee, and when he was at large, having discharged his debt. The medical officer wrote to the Commissioners in explanation, and expressed his surprise at the demand for resignation, but without effect, as the Commissioners a second and a third time reiterated the demand for his resignation.

At this stage of the affair, his medical brethren took up the case, and in repeated and respectifnl terms requested the Commissioners to grant the "accused and condemned" an investigation, inquiry, or trial; but it was refused, and the offcer was dismissed by "sealed order," and his post declared vacant. Then, on representation of the profession to the Board of Poorlaw Guardiaus, (who are distinct from, although part and parcel of the dispensary committee, as the latter consists of a number of the Board of Guardians, ) this body took up the ground which the medical men were obliged to abandon, owing to the "sealed order," and requested an inquiry, which was also refused to them. The day of election to the vacant post was announced by advertisement, and the discarded officer was put forward as a candidate, the Commissioners having declared him eligible for re-election, when the independent members of the committee voted for and carried him into office again by a majority of two to one, thus marking their sense of injustice done to him, as well as their approval of the principle for which his brethren had contended -viz., "trial by jury"-the right of every British subject.

The profession finding that the "Articles" of the Poor-law Commissioners did not define a quon um ontu of so large a committee, (consisting of sixty-six members, and feeling that with regard to "special" meetings too great latitude was given to the vice-chairman and secretary of such committee, convened by requisition, to which was appended forty-six names of the medical practitioners of the city of Cork, a meeting of the profession at large of city and county, which was held on the 10th ult., and most respectably attended, and at which a meries of resolutions was passed calling for amendment in the "Articles," which would in future render misunderstanding between committees and medical officers less likely to occur. These resolutions were forwarcled to the Chief Secretary for Ireland (Mr. Horsman), and the Poor-law Commissioners. The former acknowledged their receipt, and said that they should have his best attention; and the latter merely acknowledged their arrival at the Poor-law office.

Now, Sir, the section of the Dispensary committee who feel annoyed at the success of the united efforts of the profession in securing justice for a brother, have pledged themselves, in the case of a vacancy by resignation to the Dispensary, not to vote for any candidate resident in the county or city of Cork, and are at this moment using all their influence to bring in a perfect stranger. I forgot, above, to say that the vice-chairman and honorary secretary resigned their posts on the withdrawal by the Commissioners of the "sealed order," and the reelection of the unjustly dismissed officer. -I am, Sir, yours \&c., December, 1855 .

C. R. D. M

P.S. - The members of the profession of both county and city of Cork have formed themselves into a "Protective Association," and in future, whenever a practitioner complains of a grievance, and the grounds of complaint are just, he will receive every possible support, to have his case at least inquired into and decided upon by a proper tribunal.

* If our correspondent had read THE LANCET carefully, he would have found that on more than one occasion we have noticed the transactions to which his letter applies. -SUB-ED. L.

\section{THE LATE DEATH FROM CHLOROFORM IN EDINBURGH.}

The following account of this melancholy case has been read before the Medico-Chirurgical Society by Dr. Roberts :-

"The sudden death of a lady, while under my care for the extraction of some teeth, having been reported in several of the journals as a case of 'Death from Chloroform,' and having created a considerable sensation in the public mind, I consider it necessary to communicate the particulars of that unfortunate case, so that the profession may be enabled to judge as to the 560 cause or the association of circumstances which brought about the fatal result.

Mrs. H-, aged 36 years, tall, and rather delicate in appearance, called at 3 P.H. at my house, on Tuesday the 30 th October last, accompanied by her husband, for the purpose of having the four lower incisor teeth extracted. With the intention of dissuading her from the use of chloroform, I remarked that the operation would be very simple, as the roots were single and by no means firm; but she replied, 'Oh, but I must have chloroform. You have given it to me before, and you must give it to me now.' Her husband expressed no wish in the matter; and as I had administered chloroform to her on fou previous occasions during the last twelve months, without any unusual effect, and as I was aware that her medical attendant in the country gave it to her during her accouchement, some months previous to her first visit, I consented to its employment on this occasion also.

While preparing to sit down in the operating-chair, she said, "Have you heard of that case of death from chloroform. which occurred lately in my neighbourbood, while a person was having a tooth extracted ?' and again, when seated, she observed, 'I feel rather nervous.' My son assisted me in administering, in the usual way, the chloroform, which was the preparation of Messrs. Duncan and Flockart. Mrs. Hhad only taken about nine or ten inspirations, obtaining but the partial influence of a quantity short of a drachm and a half poured out from the bottle, and inhaling it for a space of time certainly less than a minute, when she said, "You must not operate until I am quite insensible;' and again, 'I am not over yet, you must give me more-I am not over yet;' and immediately, even while speaking, she gave a convulsive start, and with a stertorous inspiration, and with the eyes and mouth open, sunk to the floor.

The suddenness of this attack, the expression of the countenance, and the attitude, altogether so different from anything which I had ever witnessed from chloroform, although I had up to that time on my register 2096 cases, in which I had operated with the use of chloroform, immediately alarmed me, and $I$ instantly desired my son to run for Professor Simpson, whose house is close at hand, in the meantime doing all that 1 could think of to resuscitate the patient; and as Dr. Simpson was fortunately at home, he came to my assistance, accompanied by Dr. Priestley, in less than five minutes from the time that the accident had happened. The means employed were pulling forward the tongue and keeping up artificial respira. tion; and as the face was greatly congested, bleeding was attempted, but not more than six or seven ounces could be procured. Galvanism was applied alternately with artificial respiration, but produced no permanent benefit. After artificial respiration had been carried on for some time, repeated spontaneous inspirations were remarked, but at no time more frequent than five in the minute. The pulsations of the radial artery were at first not sensible, but, while the artificial breathing was going on, they became more distinct, and the livid appearance of the face in a great measure disappeared. The Sime improvement was also noticed when the galvanic current excited the muscles of respiration, which at first gave hopes of resuscitation. But, occurring as they did, more than once, ultimately decliner, and after one hour and a quarter (4 20 P.M.) of the most energetic exertions (especially on the part of Dr. Simpson), the case was reluctantly abandoned as hopeless, life being manifestly extinct.

The following is the post-mortem examination, which was made twenty-eight hours after death, by Drs. Simpson, Peddie, and Priestley, along with myself and son:-

Post-morten examination of $M r \cdot S$. $H$, twenty-eight hours after death. - The general appearance of the body presented nothing unusual. The deep livid colour of the integument of the head and neck, and the injection of the conjunctivæ, which were observable at the time of death, had in a great measure disappeared.

On laying open che abdominal walls, the organs contained in that cavity were found, in most respects, healthy. The capillaries of the intestines were, however, distended with blood, giving to the convolutions of the bowels a more than usually deep-red colour.

The liver, too, was firmly adherent by the whole of its convex surface to the diaphragm, by old lymphy exudation but when cut through, its substance revealed no other morbid change.

The uterus was healthy, and its appendages healthy.

In the dissection of the thorax, the Inngs did not appear more than ordinarily congested, except posteriorly, where they 
were of a deeper colour, and contained more blood; this was, doubtless, the result of post-mortem circumstances.

When the pericardium was laid open, the heart was found preternaturally small in comparison with the conformation of the body; the right side was flaccid and full of blood, while the left side was comparatively firm and contracted. On dividing the descending vena-cava, a quantity (probably six or eight ounces) of dark, half-coagulated blood escaped from its tributaries, and from the right auricle.

The extreme thinness of the walls of the right auricle and ventricle were remarked when they were laid open; in fact, in no portion of the muscular substance of the right ventricle did the thickness exceed one-half the normal proportions, and its component tissue was soft and lacerable.

Both right auricle and ventricle were gorged with dark blood, and the valves belonging to both cavities were healthy.

The left ventricle was contracted, and little blood remained in either ventricle or auricle of this side. The muscular parietes were thinner than usual, but the difference was less marked than on the right side.

Under the microscope, the muscular fibres of the right side of the heart, more especially of the ventricle, were much altered in appearance. The transverse striæ were indistinct, or had disappeared entirely in some portions, while fatty granules were everywhere observable, arranged in lines, along the direction of the fibres.

The same state was found to be present, but in a less degree, in the muscular tissue of the left ventricle; here, however, the fatty particles were few and scattered, and the transverse markings, for the most part, distinct.

The vessels of the brain were turgid with blood, but, beyond this, the cerebral organ appeared healthy. (Signed)

\section{J. Y. StMreson}

A. PEDDIE.

W. O. Priestley.

To these statements $I$ have only to add, that $I$ have been informed Mrs. H.'s father died some years since of disease of the heart, being found dead in his chair.

Queen-street, Edinburgh, Nov. 23, 1855."

\section{SALARIES OF UNION MEDICAL OFFICERS.}

IMPORTANT DISCUSSION TO THE MEDICAT PROFESSION.

A Special Meserng of the Guardians of the Guildford Union has just been held for the purpose of taking into consideration the salary of Mr. Gall, the medical officer of the Send and Ripley district of the above union. There was, in addition to a full attendance of Guardians, several ex-officio guardians present,- -viz., Lord Lovaine, the Honourable F. Scott, E. Bray, and James Stedman, Esqs.

It may be necessary to state that Mr. Gall has been the medical officer of the district above alluded to for several years, the salary being $£ 50$ a-year. He has, however, recently tendered his resignation, unless the amount was increased to $£ 60$. The matter was brought before the Board, and the extra amount was, after a considerable discussion, agreed to, subject to the confirmation of the Poor-law Board. On the matter being laid before them, it appeared that they did not object to the increase, but wrote to say that they did not consider Mr. Gall the then medical officer, he having resigned, and desiring that he should be re-elected.

Major ONsLow then moved that the salary be increased from $£ 50$ to $£ 60$ a-year.

Mr. STRong said he had great pleasure in seconding the proposition. Mr. Gall had held the office between twelve and thirteen years, and there had never been any complaint against him. They would, after all, have only to pay $£ 5$ of it.

$\mathrm{Mr}$. D. Hookgr, the Vice-Chairman, said he should vote against the motion. A respectable gentleman had offered to do the duty for $£ 50$. He did not see why they should raise the salary to please Mr. Gall, who was not only disturbing his own district, but all the others. It was a question of principle, and not one of $£ 5$ or 210 . It was, in fact, whether they should raise the salaries in the Union altogether.

Mr. J. STEDMAN said he had had forty years' experience, and felt much interested in the medical department of the Union. He should certainly support the proposition of Major Onslow. Medical men ran great risks in the discharge of their duties, being obliged to visit places where all kind of diseases were prevalent; and the small amount of salary could not be called a remuneration. $\mathrm{He}$ had advocated an advance on former occasions on the ground of the large amount of time the performance of the duties occupied, and the material increase in the expenses; and it appeared to him they were called upon to take a more general view of the subject. They had two duties to perform; their paramount one was to the poor, the next to the rate-payers; and he believed if they polled the whole of the Union, they would find it to be a unanimous opinion that the poor should be in a better state with reference to the medical department. $\mathrm{He}$ sincerely hoped otber unions would take up the subject, and that the poor would not, as it were, be let to the lowest bidder; for no man could do the required duty at the salaries now paid in any Union, he did not care where that Union was. Mr. Stedman then paid a high compliment to Mr. Gall for the very efficient manner in which he had performed the duties of his office. He would always rise to oppose the grinding down of the medical salaries (hear).

After a considerable discussion, Mr. JoHs Elurs, the Chairman, addressed the Board at some length. He had given the matter his consideration. He would yield to no man in his desire that the poor should have every attention, but he could not make up his mind that a general increase in the salaries of their medical men would ensure them better attendance. The Chairman then paid Mr. Gall the highest possible compliment for the way in which he had discharged his duties, He should be glad, as a Guardian, to enter into the subject of which Mr. Stedman had spoken at some other time, but they had now a subject before them upon which they were called upon to decide. They would bear in mind it was a public question, and public money, and if the matter was carried out generally it would considerably augment the expenditure of that and other unions.

The motion was then put from the Chair, when there appeared-for it, thirteen ; against, eight.

Major ONsLOw then said, on some future day he should bring forward a motion to consider the propriety of increasing the salaries of the medical officers of the union.

Mr. James SxeDMan suggested that an application should be made to the Government to pay the whole amount out of the Consolidated Fund, by which means the Government would see that medical men were properly compensated, and the Board would see that they did their duty.

It was then agreed that an advertisement should be issued for the election of a surgeon for the Send and Ripley district.

\section{FLOGGING IN THE RUSSIAN ARMY.}

EXTRACT FROM A LETTER FROM THE CAIUP BEFORE SEBASTOPOI.

"I Found in the Redan an immense number of reports of surgical and medical cases treated in the hospital of the Karabelnaia. I cannot imagine for what purpose they were brought up to the Redan. Many of them were of old dates, as far back as 1839. They are all drawn out after one fashion. Each case is on a separate sheet of paper, or on several sheets tacked together, so that it is complete from the admission to the termination. At the head is the patient's name, rank, regiment, date of admission, \&c. Five columns are then ruled, along which are entered the record of the case and treatment. The record is made in Latin, not always of the purest and most classical style. In the first column is the date, day by day, of entry; in the second, the " historia morbi, symptomata, \&c.'; in the third and fourth columns the 'ratio medendi' is ,entered, divided severally into the 'medicamenta interua' and 'remedia externa'; in the fifth and last column is the 'dieta.' The diet is divided into three classes, distinguished as the first, seccnd, and third; the first answering apparently to our 'spoon,' the second to our 'low,' and the third to our ' full,' diet. I brought a large bundle of the cases away, which I will take an early opportunity of sending you for your edification. There are a number of cases of 'vibices'-a class you have, fortunately, no opportunity of treating in civil practice. I wish we had not either, as my experience leads me to think them to be about as beneficial in their moral effect as they are in their physical effect on the constitution, which, I need hardly say, is minus nil. However, the knout does not appear to be so severe after all as our 'cat-o'-nine-tails,' or else the Russian hides bear tanning better; for, except in one instance, I see all the patients were well after one day's hospital treatment. This does not happen with our admissions under pruritus, notwithstanding the limited number of lashes. I will note a few for you in the order they happen to come. You will observe the flogging is not about the region of the scapula, where our drummers, if they are good artists, chiefly throw 